\title{
Lost in translation. Homer in English; the patient's story in medicine
}

\author{
Robert J Marshall, ${ }^{1}$ Alan Bleakley ${ }^{2}$
}

${ }^{1}$ Cornwall Health Campus, Knowledge Spa, Royal Cornwall Hospital, Truro, Cornwall, UK

${ }^{2}$ Collaboration for the Advancement of Medical Education Research and Assessment (CAMERA), Plymouth University Peninsula School of Medicine, Plymouth, Devon, UK

\section{Correspondence to} Dr Robert J Marshall, Cornwall Health Campus, Knowledge Spa, Royal Cornwall Hospital, Treliske, Truro, Cornwall TR1 3HD, UK; Robert.marshall@pms.ac.uk

Received 27 October 2012 Revised 16 January 2013 Accepted 28 January 2013 Published Online First 28 February 2013

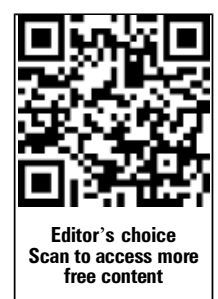

To cite: Marshall RJ Bleakley A. Med Humanit 2013;39:47-52.

\section{ABSTRACT}

In a series of previous articles, we have considered how we might reconceptualise central themes in medicine and medical education through 'thinking with Homer'. This has involved using textual approaches, scenes and characters from the lliad and Odyssey for rethinking what is a 'communication skill', and what do we mean by 'empathy' in medical practice; in what sense is medical practice formulaic, like a Homeric 'song'; and what is lyrical about medical practice. Our approach is not to historicise medicine and medical education, but to use thinking with Homer as a medium and metaphor for questioning the habitual and the taken-for-granted in contemporary practice.

In this article, we tackle the complex theme of 'translation'. We use the lens of translation studies to examine the process of turning the patient's story into medical language. We address the questions: what makes a 'good' translation? What are the consequences of mistranslation and poor translation? And, while things are inevitably lost in translation, does this matter?

'Translation it is that openeth the window, to let in the light' (preface to King James Bible).

\section{INTRODUCTION}

In a series of articles, ${ }^{1-4}$ we have considered how we might reconceptualise central themes in medicine and medical education through 'thinking with Homer'. This has involved using textual approaches, scenes and characters from the Iliad and Odyssey for rethinking what is a 'communication skill' ${ }^{1}$ and what we mean by 'empathy' ${ }^{2}$ in medical practice; in what sense is medical practice formulaic, like a Homeric 'song'; ; and what is lyrical about medical practice ${ }^{4}$ ? Our approach is not to historicise medicine and medical education, but to use thinking with Homer as a medium and metaphor for questioning the habitual and the taken-for-granted in contemporary practice.

In this article, we tackle the complex theme of 'translation'. We use the lens of translation studies to examine the process of turning the patient's story into medical language. We address the questions: what makes a 'good' translation? What are the consequences of mistranslation and poor translation? And, while things are inevitably lost in translation, does this matter?

\section{RECEIVING A HISTORY}

'Taking a history' is the process of rephrasing the story a patient tells into specialist medical language. Our students at Peninsula College of Medicine and Dentistry, UK, were encouraged not to 'take' a history, but to 'receive' it, a change designed to emphasise the importance of listening, of giving the patient a voice. However, intervention at this first level of translation is often lost at a second level, when the history is converted into a written, permanent record. Here, the patient's voice is usually lost in translation.

'Taking' a history can have serious unintended consequences. It is an old saw in medicine that most of the diagnosis can be found in the patient's story. William Osler's most famous saying was 'listen to your patient, he is telling you the diagnosis'. Yet, between $10 \%$ and $15 \%$ of patients seen in primary care specialties (family medicine, internal medicine and paediatrics) are misdiagnosed. ${ }^{5}$ This does not matter when the patient gets better, or gets worse but returns to the doctor. However, some misdiagnoses can lead to adverse effects. Lucian Leape and colleagues ${ }^{6}$ studied more than 30000 hospitalised patients' records to discover that diagnostic errors accounted for $17 \%$ of adverse events; and misdiagnosis is a leading cause of malpractice claims in the USA. ${ }^{5}$

Recognising the importance of listening closely to patients' stories, 'narrative medicine' has become the dominant form of the medical humanities. Literature is a great source for learning not only empathy, but also ethics. Contemporary narrativists in the medical humanities warn us against overinterpretation of patients' stories. Johanna Shapiro ${ }^{7}$ fears narrative medicine becoming inflated through smart textual approaches that question the authenticity or reliability of patients' stories, calling for 'narrative humility' from researchers. Wear and Aultman ${ }^{8}$ warn that exposing medical students to discomfiting literature can produce defensiveness and resistance to confronting issues central to good medical practice, such as inequality and oppression. Students readily tolerate benign plots and characters, where transgressive and challenging plots and characters at first produce resistance rather than empathy. This does not mean that we avoid use of challenging literature, but that we are aware of potential resistance as an issue of translation across literary and medical metaphors and mindsets.

Claire Hooker and Estelle Noonan ${ }^{9}$ point to the medical humanities' largely unexamined western imperialistic tendencies, an issue that we explore later, in relation to the translator as potential imperialist. We can develop this idea. Where 'narrative' is framed as story understood by privileged 'Westerners', 'other' cultures have other ways of framing, telling and listening to story. Of course, the lay patient is 'other' to the professional doctorthey already inhabit different territories. Listening is the first part of the process of translation, but doctors have to record what happens; and, in teaching students and juniors, relay what they gleaned 
from listening to patients, medical colleagues and other healthcare professionals. Further, this happens both formally (case notes, case meetings, ward rounds), and informally (corridor conversations, coffee room chat, slips of confidentiality at social events).

\section{TRANSLATION MATTERS}

The interaction between patient and doctor is a transaction that involves translation, where: 'the physician's concern is to translate the subjective experience of illness into the recognisable discourse of medicine', ${ }^{10}$ and 'Diagnosis is a thoroughly semiotic activity: an analysis of one symbol system followed by its translation into another'. ${ }^{11}$ Research notes that much is lost in translation during this transaction. ${ }^{12}$

While clinical encounters have been studied as social transactions-interpersonal communications or teamwork effects-they have not been looked at from the point of view of translation studies. Here, we mobilise study of translations of Homer as a lens through which we can rethink, in particular, doctor-patient encounters.

While medicine is constantly translating technically, we can only get to grips with technical issues, such as the chemistry of nucleic acids and proteins, through metaphor. So, the coded information of DNA is read and transcribed by 'messenger' RNA, which translates it into amino acids that are the building blocks of proteins. This is by means of transfer-RNA ('transfer' is from the same Latin root as 'translate'). Translation is a metaphorical practice. 'Translation' is also commonly used to refer to putting theory or ideas into practice, or applying research findings. 'Translational medicine' is the process of turning medical research into artefacts (medical devices, drugs) and practices that can be used in the treatment of patients.

\section{ISSUES OF TRANSLATION IN HEALTHCARE CONTEXTS}

There are four commonly encountered issues of translation in healthcare. First, the literal problem of translation, where healthcare workers globally struggle to understand patients whose language is not their own. While this is not the focus of this article, we are interested in the persistent idea that translation should be literal, or faithful to the original. While patientcentred medicine encourages understanding of, and respect for, the patient's perspective, it is hard to see how doctors can remain faithful to every account that a patient brings. 'Close reading' and interpretation of the 'patient as text' ${ }^{13}$ comes with the job. Patients' accounts are not necessarily trustworthy, and dialogue between doctor and patient is a process of negotiation of meanings.

Second, are translations between patients and healthcare providers. This area has been introduced above. A metareview by Roter and $\mathrm{Hall}^{12}$ on studies of communication in medicine reveals generally poor translations by doctors of patients' stories leading to misunderstandings, misdiagnoses and inappropriate treatments. This is acute in psychiatry, where, for instance, the more bizarre and florid symptoms of psychosis are often like a language from 'another country' that does not literally exist. While orthodox treatments eschew issues of translation by attempting to normalise 'bizarre' expressions through chemical and psychological treatments, more radical methods have attempted to translate across borders. For instance, the schizophrenic communities set up by Felix Guattari ${ }^{14}$ in France and Ronald Laing ${ }^{15}$ in the UK explicitly set out to understand the world of psychosis not by translating that language into the reductive terminology of the current Diagnostic and Statistical Manual of Mental Disorders, but by inhabiting the territory and language games of psychosis as a legitimate, indeed, poetic expression. Laing ${ }^{16}$ then translates both neurotic and psychotic symptoms as a series of 'knots' or complex encounters expressed as poems.

It is debatable as to whether or not Laing and associates were guilty of romanticising the suffering of psychotic people, and this reminds us that translation is not necessarily benign. Indeed, where the 'antipsychiatrists' claimed that conventional psychiatric treatments offered an imperialism, a conquering and control of a state (of mind), the radical interventions (or conscious non-interventions) of the antipsychiatrists might also be seen as a form of imperialism, colonising the vulnerable.

Third, is the issue of translation across colleagues at two levels -between healthcare and healthcare support professions, and between specialties in medicine. Given the increasing use of symbols, abbreviations and acronyms in the medical record, it already often looks like another language, inviting loss of nuances of meaning in the process of translation. Mistranslation and loss in translation are commonly encountered between professions even when working in the same team, but more commonly between teams. For instance, where nurses typically work to 'time', allocated democratically between patients, surgeons typically work to 'task'-finishing whatever needs to be done however long it takes. Psychiatrists working with arts therapists find that the latter are more psychologically oriented therapeutically and tend not to 'medicalise' the patient. This approach is not readily translated across the medical blood-brain barrier, where drug therapies are currency. In terms of specialty communication, a study of the rhetoric used in referral letters for the same patient across specialties reveals issues of mistranslations of meaning. ${ }^{17} \mathrm{~A}$ surgeon treating a knife wound writes an innocuous letter to a patient's general practitioner (GP) informing her of optimal follow-up treatment, where a psychiatrist writes about the same patient informing the GP that the fight the patient got into that caused the knife wound was probably due to instability in withdrawing from a long-term antipsychotic medication.

Fourth, (mis)translations between colleagues reveal that patient's 'conditions' are enacted differently across different specialties. For instance, Annemarie $\mathrm{Mol}^{18}$ shows that cardiologists, vascular surgeons, nurses, radiologists, pathologists, laboratory scientists and patients enact 'atherosclerosis'-hardening of the arteries-differently. The condition is not 'understood' technically in differing ways, rather it is 'experienced' differently, offering a variety of ontologies. Thus, 'a plaque cut out of an atherosclerotic artery is not the same entity as the problem a patient with atherosclerosis talks about in the consulting room, even though they are both called by the same name'.

In the following section, we begin to grapple with how 'thinking with Homer' might illuminate such issues of translation in medical contexts. We argue that translation studies themselves can throw light in particular on the critical first step of medicine's translation of 'person' into 'patient'. We will examine translations of Homer, using them as templates to open up the question of how translation studies can be applied to medicine and medical education, particularly to better understand the process of taking/receiving a history. Our method is to investigate both likenesses and striking contrasts between medicine and literary translation. We recognise that this engages us in metatranslation.

\section{TRANSLATING HOMER}

There are hundreds of translations of Homer. Let us take a scene from the beginning of the Iliad, where Achilles quarrels with Agamemnon, setting the tone and theme for the rest of the 
epic. Achilles is about to draw his sword and kill Agamemnon but Athene, his goddess mother, stops him. Rieu ${ }^{19}$ is one of the best-known translators of the modern era (though his translation is now nearly 60 years old). This is his version of the quarrel:

'Not that Achilles was appeased. He rounded on Atreides' (Agamemnon) 'once again with bitter taunts. "You drunken sot," he cried, "with the eyes of a dog and the courage of a doe! You never have the pluck to arm yourself and go into battle with men or to join the other captains in an ambush-you would sooner die. It pays you better to stay in camp, filching the prizes of anyone that contradicts you, and flourishing at your peoples' cost because they are too feeble to resist"'.

Here is Chapman ${ }^{20}$ (the Chapman who so moved Keats):

Thou ever-steep'd in wine,

Dog's face, with heart but of a hart that nor in th' open eye

Of fight dar'st thrust into the press, nor with our noblest lie

In secret ambush. These works seem too full of death for thee:

Tis safer far in th'open host to dare an injury

To any crosser of thy lust. Thou subject-eating king!

Base spirits thou govern'st, or this wrong had been the last foul thing

Thou ever author'dst.

And this is the same passage translated by Fagles ${ }^{21}$ :

Staggering drunk, with your dog's eyes, your fawn's heart! Never once did you arm with the troops and go to battle Or risk an ambush packed with Achaea's picked men -

You lack the courage, you can see death coming.

Safer by far, you find, to foray all through camp;

Commandeering the prize of any man who speaks against you.

King who devours his people! Worthless husks, the men you rule -

If not Atreides, this outrage would have been your last.

And finally, this is the version of the poet Christopher $\operatorname{Logue}^{22}$ :

'Mouth! King Mouth!'

Then stopped. Then from the middle sand said:

'Heroes, behold your king -

Slow as an arrow fired feathers first

To puff another's worth,

But watchful as a cockroach of his own.

Behold his cause -

Me first, me second,

And if by chance there is a little left-me third.

Behold his deeds -

Fair ransom scanted, and its donor spurned.

The upshot-plague.

O Agamemnon, O King Great I Am,

The Greeks who follow you, who speak for you,

Who stand among the blades for you,

Prostitute loyalty.'

These four translations raise many of the issues that run through translation studies. While the scene is the same, fundamentally different things happen in each. This can be compared with Mol's ${ }^{18}$ reading of the differing ontologies of 'atherosclerosis'.

Rieu has translated poetry into prose, a translation that many have considered prosaic. The version of Fagles is a well-known modern translation. It is in verse and sticks closely to the Greek original. One wonders whether the verse is more in form than spirit. It reads like prose sliced into lines of roughly even length and the metre is hard to find. It certainly does not capture the relentless beat of Homer's hexameters, clearly reflected in
Chapman's verse. Chapman gives greater gravity to the epic tragedy by using iambic heptameters-'fourteeners'-a rhythm evocative of trotting horses, as in the last line: 'And so horsetaming Hector's rites gave up his soul to rest'. He gives a lighter, but more grounding, rhythm to the Odyssey (which is part comic in genre) through iambic pentameters: 'Now when with rosy fingers, th'early born/ And thrown through all the air, appear'd the morn'. This is the rhythm used by Shakespeare, based on the heartbeat (lub-dup, lub-dup, lub-dup, lub-dup, lub-dup): 'Once more unto the breach, dear friends, once more; Or close the wall up with our English dead'.

The modern poet Christopher Logue is perhaps the most exciting of the four translators. He is bold in his recreation of the story, moving a long way from the Greek, and it can be difficult to recognise many of the passages in the original. Logue did not read Homer in the original Greek; his poetry is taken from translations, and so is a translation of a translation.

What relevance does this have to the medical encounter? Let us turn to a patient history for some illumination:

I was out shopping when my vision suddenly went very strange. It became fuzzy and blurred in my right eye; the image got all mixed up and then briefly moved to blurring on the left side. There was an impression of double vision. I had something similar about a year ago, but that was with slight weakness on my right side and the visual disturbance was not the same.

This might appear in the patient's record as a truncated translation: 'sudden onset of blurred, ?double vision. h/o previous TIA-like attack' (where h/o is 'history of', and TIA is transient ischaemic attack-a sort of minor stroke). The patient's story and that in the medical record might be taken as the two ends of the translation spectrum. (In fact, no patient is as fluent as this example. The account would be punctuated by ums and ers, repetitions and corrections-and almost certainly interruptions by the doctor). What are the issues here for doctors as translators? In the following sections, we consider four issues: faithfulness to the original, identity, power and contingency.

\section{FAITHFULNESS TO THE ORIGINAL}

Translators are clear on the difference between transcribing legal documents, when faithfulness to the original is paramount, and translating, say, a speech, when the motive behind the words may justify moving a considerable way from literalness. Where does the patient's narrative fall in this spectrum? The modern medical history retains little in quotation marks and the diagnostic process is designed to move away from the individual narrative to a more universal language.

However, more importance is placed on the written account and its literal echoing of the patient's story now that there is more frequent recourse to the law (ironically, where patients largely sue for malpractice through misdiagnosis-the area of the doctor's work that, as we have said, traditionally relies on listening closely to the patient's story).

Translators are much concerned with faithfulness, with the issue of what constitutes a faithful rendering of the original. This is part of the folklore of translating, deriving from the closeness of the two words in Italian-traditore and traduttore, and ultimately in Latin. ${ }^{23}$ Three etymologies are involved. All of them are based on 'trans' in some form, meaning 'across'. 'Translate' derives from transferre (past participle translatum) meaning 'to carry across'; traditore from tradere (an elision of trans and dare)-'to give over' and hence betray; and traduttore (an elision of trans and ducere)—'to lead over'). 
Translation studies recognise a spectrum of changes from those adhering closely to the original to those that give a much freer interpretation. Louise Haywood ${ }^{24}$ illustrates this spectrum from the 'interlinear' to the 'ideomatising' through an Italian sentence-Le piace molto la novella del Boccaccio. The 'interlinear' is the literal or faithful translation: 'To her pleases much the story of the Boccaccio'. This awkward version can be improved, as: 'She likes the story by Boccaccio very much'. The 'ideomatising', however, would move further to: 'She's mad about the Boccaccio', an interpretation of the original. Note that Haywood misses the extremely literal translation or transcription of the linguistic researcher, who may leave marks for pauses and 'ums' and 'ers'.

The issue of being faithful is not a simple one. In 1861, Matthew Arnold ${ }^{25}$ while Professor of Poetry at Oxford University, gave a famous series of public lectures-On Translating Homer. He asked the prior question of precisely what we mean by 'faithfulness'. Most translators inevitably resort to metaphor and rhetoric for explanation. Cicero, ${ }^{26}$ in rendering the speeches of Demosthenes into Latin, was clear that his duties lay as much with his role of orator as of translator. Cicero rejects literal translation for 'weight' or quality: 'I did not think it necessary to translate word for word, but have kept the spirit and force of the originals. For I thought I ought to give the reader not the number of the words, but their weight.'

The doctor's translation-from patient to record, across colleagues, in texts-may then follow both Arnold's and Cicero's recommendations, that 'faithfulness' can be interpreted in a number of ways, and that 'weight' is more important than literality. Standard translation through medical tropes is one of the ways in which medicine retains professional identity as a community of practice.

Doctors have to reduce the patient's story for functional reasons, otherwise there is simply too much information. This reduction of the patient's story is not only practical, it can be recognised as aesthetic, within the genre of Minimalism, only saying what needs to be said, but with elegance. It may easily happen, however, that a critical piece of information is not recognised and is lost in that shortening. But not all translation is reductive. Insertion and addition may also occur for several reasons: thoughtlessness, clarity, or even emphasis through pun. In Chapman's ${ }^{20}$ translation earlier, for instance, 'heart but of a hart' is a fair word-for-word rendering of the original, but introduces a pun not in Homer. Doctors should be aware of the subtle meanings of such punning. Analogy, for instance, is used widely in pattern recognition diagnoses as a kind of punning, sometimes outwardly cruel in its twinning of the desired and the undesired-for instance 'chocolate cyst' in an ovary, 'apple core lesion' for colonic cancer. ${ }^{27}$

As for the spirit of the original, Arnold's ${ }^{25}$ distillation of this spirit of Homer is widely quoted and used still as a yardstick to assess translations:

that he is eminently rapid; that he is eminently plain and direct, both in the evolution of his thought and in the expression of it .... that he is eminently plain and direct in the substance of his thought, that is, in his matter and ideas; and, finally, that he is eminently noble.

Arnold himself describes these as 'qualities' typifying Homer, rather than the 'spirit' of Homer. Of our examples above, one might argue that Logue's interpretation of a translation best captures these qualities of vigour, movement and passion, and Rieu's the least. But Logue is a highly imaginative, 'embodied' or sensual poet. Most doctors would argue that not only is the medical narrative devoid of this vigour and passion, but that such qualities have no place in a medical context. We disagree, as our parallel drawn between medical histories and Minimalist art above suggests. The point is to turn an instrumental account into an aesthetically pleasing or challenging one, or to give form to the formless. What is aesthetic by definition grips, engages and educates the senses. This is surely the whole point of introducing the humanities into medical education. A story of crushing central chest pain can be very vivid even on the 100th retelling, and the medical rendering may be an emotional catalyst for thought and action.

\section{IDENTITY}

The identity of the 'doctor' can be thought of as multiple-for instance, doctor as scientist, professional, humanist, team player, manager and educator ${ }^{13}$ _ but what of doctor as 'translator'? The translator's identity is nebulous, probably best captured by the title of Venuti's ${ }^{28}$ book The Translator's Invisibility-an invisibility noted by Dryden ${ }^{29}$ : 'But slaves we are, and labour on another man's plantation; we dress the vineyard, but the wine is the owner's ... we are not thanked; for the proud reader will only say the poor drudge has done his duty'.

The variety in the translations of Homer is extreme but shows that this is not an unimportant matter. This invisibility is dangerous. It suggests the foreign text can pass into another target language pure and unmediated. The medical translator, probably the most junior of the team, is likely to be similarly invisible. As with other translators, she may be unaware of the constraints that identity formation can impose. Nearly every aspect of the written medical history is formulaic: the order of events, the layout, the use of abbreviations and the extent that the patient's voice can be quoted are all defined. This can be helpful to the novice to avoid omitting important information, and to other doctors in helping the rapid assimilation of detail. Rabin ${ }^{30}$ describes how translation is dependent on the extent of previous translation, because it builds a stock of tropes that deals with translation problems. The canon of practice, however, especially in medicine, is mostly unconscious and unrecognised. It may then limit expression and censor the transmission of information. Again, it is a cliché in medicine that the diagnosis rests in the patient's story. A critical diagnostic clue may therefore be lost with the omission of that item in the history.

Perhaps the most striking equivalence between translator and doctor is in the ethics of practice-obvious in medicine, less so in translation, at least for the non-translator. But for translators, it is critical and a theme that recurs. Spivak, ${ }^{31}$ for instance, the main translator of Derrida into English, says: 'First, then, the translator must surrender to the text ... no amount of tough talk can get around the fact that translation is the most intimate act of reading. Unless the translator has earned the right to become the intimate reader, she cannot surrender to the text, cannot respond to the special call of the text'. Venuti ${ }^{32}$ talks of 'The violence of translation (residing) in its very purpose and activity ... Translation is the forcible replacement of the linguistic and cultural difference of the foreign text with a text that will be intelligible to the target-language reader.'

The medical translator reacts strongly to the notion that she is engaged in anything aggressive or violent. The ethics of her practice would currently encompass confidentiality and the qualities needed for close and empathic listening. Translation studies should open medical eyes to the possibilities of aggression and acquisitiveness, and deeper consideration of a process that has, to some extent, to be intrusive. The intrusive nature of the 
physical examination of the patient, particularly intimate examination, has been stressed in medical education for decades. The metaphorical language in translation studies of intrusion and aggression is another way in which light can be shed on the everyday activity of 'taking a history'.

All the above argue for the likeness between the translator and doctor in their roles in terms of being undervalued. There is a far more important difference-that the participant most likely to be rendered invisible in the medical scenario is the patient, the source 'text'. ${ }^{13}$ It is interesting to look for parallels, however. Logue's translations are far from the original, but the source in Homer can generally be identified. Much further from the source is the text of Alice Oswald, ${ }^{33}$ whose poem, Memorial, runs through the deaths of all the heroes in the Iliad, giving a brief biography, followed by a repeated simile for most of them. For instance:
'Brave Hypsenor the stump of whose hand
Lies somewhere on the battlefield
He was the son of Dolophon the river-priest
Now he belongs to a great red emptiness
Like when the rainy fog pulls down its hood on the mountains
Misery for the herdsman better than night for the thief
You can see no further than you can throw a stone
Like when the rainy fog pulls down its hood on the mountains
Misery for the herdsman better than night for the thief
You can see no further than you can throw a stone

This is a very long way from Homer (which does not mean that Oswald's poem lacks other merits). Not only is the bulk of the story excised and the main characters, except Hector, almost unmentioned (because they survive within the timescale of the Iliad), but the biographies are often not in the Iliad and the similes, for which Homer was famous, often quite different. However, difference from the original does not mean that no light is shed on it. The sheer number of deaths and the poignancy of the brief biographies and the strangeness of the similes make one re-examine these features in the original.

Medical rituals can act as translation 'intermediaries, 34 35 mere repositories of habits-rather than 'mediators', 34 frustrating potential innovations in practices. Nearly every aspect of the written medical history is formulaic: the order of events, the layout, the use of abbreviations, and the extent that the patient's voice can be quoted are all defined. Why medical error continues at such a high and unacceptable rate as a consequence of poor clinical teamwork, and failing to listen closely to patients' stories, may be because new networks are not being initiated, as translations fail across actors stuck in habitual practices. While the patient is the source text, he or she has not been exposed to 'close reading', and varieties of translations have not been closely examined.

\section{POWER}

Translation is an instrument of power in the hands of the translator, who can exercise a kind of 'violence'. Venuti ${ }^{28}$ notes 'the power of translation to (re)constitute and cheapen foreign texts' and 'to trivialise and exclude foreign cultures'. In a psychoanalytic reading, Venuti ${ }^{28}$ argues that Robert Graves' translation of the Roman writer Suetonius entirely misrepresents the Latin original, where

Graves' interpretation ... assimilates an ancient Latin text to contemporary British values. He punctures the myth of Caesar by equating the Roman dictatorship with sexual perversion, and this reflects post-war homophobia that linked homosexuality with a fear of totalitarian government, communism, and political subversion through espionage.

Goethe $^{36}$ noted such potential cultural imperialism two centuries ago:

There are two maxims in translation: one requires that the author of a foreign nation be brought across to us in such a way that we can look on him as ours; the other requires that we should go across to what is foreign and adapt ourselves to its conditions, its use of language, its peculiarities.

What does the doctor think she is doing in these terms? How much is she straining to avoid the 'abusive fidelity' that, Venuti ${ }^{28}$ argues, masks much of cultural dominance? Should she bring the patient story over into the target language of medicine, or travel over to the patient to preserve the 'foreignness' of that language? The language of the medical history is so far from what the patient says that this discussion may seem irrelevant, but the doctor ought to claim a close or exact correspondence between the two. So, in terms of this discussion, is this 'abusive fidelity'? Certainly, the feel of the original account is usually lost completely as emotional content and context are both lost entirely in formal translation to a medical record, but may be impressed in the memory of the doctor as an informal record.

\section{CONTINGENCY}

By 'contingency' we mean circumstances such as time, place and specialty, largely outside the control of the translator and doctor as translator, that influence their textual practices.

The era in which Homer was translated makes striking and obvious differences to the translation. The Penguin translations by Rieu had an overtly democratising purpose. It is interesting to ponder the 'best way' of translating Homer, if one were attempting a new version outside the limitations of culture. If one cuts short a long argument and accepts that poetry must be rendered by poetry and that Greek dactyls must be rendered by English iambics, there remains an interesting argument about whether an archaic rendering is not closest to how Homer was received in the classical world. The Iliad had to be contemporary at some point, but even when first written down around the 7th century BCE (Before the Christian Era), it was already quite old, sounding perhaps rather Shakespearian then, and certainly in the later Athens of Plato and Aristotle. The translations of Chapman and Pope may therefore give us the closest feel of Homer.

Our doctor is equally constrained by the context in which she works. Different fashions of the layout of the hospital record have prevailed over the years; even keeping a record in primary care in the UK was not universal in Britain 50 years ago. The computerised medical record of the future will transform how the patient story is preserved.

The issue of specialty pertains to both translator and doctor. Logue is a poet, whose possible interest in democratisation would not extend to a prose translation, while prose underlay the principles of Rieu. Fagles sounds like a classicist and translator rather than a poet, for reasons given earlier. The type and quality of translation depend then on the background and expertise of the translator. In medicine, the specialty again affects how the patient's story is recorded and how it is translated rhetorically between specialty interests. ${ }^{17}$ The narrative of the immediate problem, the 'past medical history' and the social circumstances are more likely to be recorded by the psychiatrist than the surgeon (though the last will be closely recorded by other specialists within the surgical department, such as the occupational therapist and physiotherapist). 
The issue of the social circumstances of translator/doctor or, on a broader canvas, the cultural milieu in which they operate has already been touched on in the section on identity. There, the accent was on the appropriate language of translationwhether it should reflect the strangeness of the original or be brought entirely into the fluency of the target language. Here, we deal with language and culture rather than language in culture. For the doctor, the difference is between capturing the nuances of a patient's description and recognising the different constructs of health and disease within which they might operate - there is a local Cornish farmer known to one of the authors, for instance, who treats his abnormal heart rhythms by jumping off the barn roof onto his heels.

\section{CONCLUSION}

This article is intended to shed light particularly upon the movement of story from patient to doctor, using the lamp of translation studies. It is of academic interest to consider the taking/receiving and recording of a medical history, but we would prefer to see a practical advantage to patients and their care. We do not intend to paralyse activity by overanalysing. Translators themselves recognise this risk and accept that they must be practical:

Translators are never, and should never be forced to be ... neutral, impersonal transferring devices. Translators' personal experiences-emotions, motivations, attitudes, and associationsare not only allowable in the formation of a working TL (target language) text, they are indispensable. ${ }^{37}$

Our purpose has not been to set out a programme for translation in medicine, to legislate on best practice. Rather, we have drawn on translation studies-applied to Homer in particularfirst to raise awareness about the importance of translation; second, to draw attention to the value of recognising and articulating translations where these form networks or support for practice innovation; and third, we show how faithfulness to the original, and factors such as identity, power and contingency are key and contested factors in translation in medicine. We encourage doctors to not take translation for granted, but to consider its complexities, as they take on the identity of doctor as translator. Patients take their illnesses seriously; doctors take their interactions with patients seriously; and the power of translation can do justice to both. Thinking with Homer can shed light on the power of translation.

Contributors Both authors contributed to the writing of this article.

\section{Competing interests None.}

Provenance and peer review Not commissioned; externally peer reviewed.

\section{REFERENCES}

1 Marshall RJ, Bleakley A. Putting it bluntly: communication skills in the lliad. Med Humanit 2008;34:30-4.

2 Marshall RJ, Bleakley A. The death of Hector: pity in Homer, empathy in medical education. Med Humanit 2009;35:7-12.

3 Marshall RJ, Bleakley A. Sing, muse: songs in Homer and in hospital. Med Humanit 2011;37:27-33.
4 Bleakley A, Marshall RJ. The embodiment of lyricism in medicine and Homer. Med Humanit 2012;38:50-4.

5 Sanders L. Diagnosis: dispatches from the frontlines of medical mysteries. London: Icon Books, 2010.

6 Leape $\mathrm{L}$, et al. The nature of adverse events in hospitalized patients: results of the Harvard Medical Practice Study II. N Engl J Med 1991;324:377-84.

7 Shapiro J, Brennan TA, Laird N. Illness narratives: reliability, authenticity and the empathic witness. Med Humanit 2011;37:68-72.

8 Wear W, Aultman JM. The limits of narrative: medical student resistance to confronting inequality and oppression in literature and beyond. Med Educ 2005;39:1056-65.

9 Hooker C, Noonan E. Medical humanities as expressive of Western culture. Med Humanit 2011;37:79-84.

10 Hunter KM. Doctors' stories. The narrative structure of medical knowledge. Princeton, NJ: Princeton University Press, 1991: 53.

11 Kleinman A. The illness narratives. Suffering, healing and the human condition. New York, NY: Basic Books, 1988: 16.

12 Roter DL, Hall JA. Doctors talking with patients/ patients talking with doctors: improving communication in medical visits. 2nd edn. London: Praeger, 2006.

13 Bleakley A, Bligh J, Browne J. Medical education for the future: identity, power and location. Dordrecht: Springer, 2011.

14 Dosse F. (Trs. D Glassman). Gilles Deleuze and Félix Guattari: intersecting lives. New York, NY: Columbia University Press, 2010.

15 Burston D. The wing of madness: the life and work of R. D. Laing. 2nd edn. Cambridge, Mass: Harvard University Press, 1998.

16 Laing RD. Knots. 2nd edn. Harmondsworth: Penguin Books, 1972.

17 Lingard L, Hodges B, MacRae $\mathrm{H}$, et al. Expert and trainee determinations of rhetorical relevance in referral and consultation letters. Med Educ 2004;38:168-76

$18 \mathrm{Mol}$ A. The body multiple: ontology in medical practice. Durham, NC: Duke University Press, 2002: vii-x.

19 Rieu EV. (Trs.) Homer. The Iliad. London: Penguin Books, 1950 Bk1 225-32.

20 Chapman G. (Trs.) Chapman's Homer. The Iliad and the Odyssey. Ware: Wordsworth Editions Limited, 2000: Iliad Bk1 225-32.

21 Fagles R. (Trs.) Homer. The Iliad. London: The Folio Society, 1999: Bk1 225-32.

22 Logue C. Kings. London: Faber and Faber, 1992: 14.

23 Weissbort D, Eysteinsson A. Translation-theory and practice. A historical reader. Oxford: Oxford University Press, 2006:3.

24 Haywood L. Translation emergency toolkit. http://www.mml.cam.ac.uk/call/ translation/toolkit/ (accessed 9 Aug 2012)

25 Arnold M. On translating Homer. New York, NY: Routledge and Sons, 1905: 10.

26 Cicero. De optimo genere oratorum. In: Wilkins AS, ed. M Tulli ciceronis. Rhetorica. Oxford: Oxford University Press, 1903:5:14. (Translated RJM).

27 Bleakley A, Farrow R, Gould D, et al. Making sense of clinical reasoning: judgement and the evidence of the senses. Med Educ 2003;37:544-52.

28 Venuti L. The translator's invisibility. A history of translation. London: Routledge, 2002: 208-23.

29 Dryden J. 'Dedication to the Aeneid'. Preface to his translation of 'The works of Vergil'. London, 1697: 82. http://www.bartleby.com/13/1002.html (accessed 2 Aug 2012).

30 Rabin C. The linguistics of translation. In: Smith $\mathrm{AH}$, ed. Aspects of translation. Vol 5. London: Secker and Warburg, 1958: 123-45.

31 Spivak GC. Outside in the teaching machine. New York and London: Routledge, 1993: 183.

32 Venuti L. Translation as cultural politics: regimes of domestication in English. Textual Pract 1993; 7:208-23.

33 Oswald A. Memorial. London: Faber and Faber, 2011: 20.

34 Latour B. Reassembling the social: an introduction to actor-network-theory. Oxford: Oxford University Press, 2007

35 Bleakley $A$. The proof is in the pudding: putting actor-network-theory to work in medical education. Med Teach 2012;34:462-7.

36 Goethe JW. Zum bruderlichen andenken wielands. In: Weissbort D, Eysteinsson A, eds. Translation - theory and practice. A historical reader. Oxford: Oxford University Press, 2006: 200.

37 Robinson D. The translator's turn. Baltimore, Maryland: The Johns Hopkins University Press, 1991: 259-60. 